\title{
The influence of dynamic vegetation on the present-day simulation and future projections of the South Asian summer monsoon in the HadGEM2 family
}

\author{
G. M. Martin and R. C. Levine \\ Met Office Hadley Centre, FitzRoy Road, Exeter, UK \\ Correspondence to: G. M. Martin (gill.martin@metoffice.gov.uk)
}

Received: 26 July 2012 - Published in Earth Syst. Dynam. Discuss.: 3 August 2012

Revised: 17 October 2012 - Accepted: 29 October 2012 - Published: 28 November 2012

\begin{abstract}
Various studies have shown the importance of Earth System feedbacks in the climate system and the necessity of including these in models used for making climate change projections. The HadGEM2 family of Met Office Unified Model configurations combines model components which facilitate the representation of many different processes within the climate system, including atmosphere, ocean and sea ice, and Earth System components including the terrestrial and oceanic carbon cycle and tropospheric chemistry. We examine the climatology of the Asian summer monsoon in present-day simulations and in idealised climate change experiments. Members of the HadGEM2 family are used, with a common physical framework (one of which includes tropospheric chemistry and an interactive terrestrial and oceanic carbon cycle), to investigate whether such components affect the way in which the monsoon changes. We focus particularly on the role of interactive vegetation in the simulations from these model configurations. Using an atmosphere-only HadGEM2 configuration, we investigate how the changes in land cover which result from the interaction between the dynamic vegetation and the model systematic rainfall biases affect the Asian summer monsoon, both in the present-day and in future climate projections. We demonstrate that the response of the dynamic vegetation to biases in regional climate, such as lack of rainfall over tropical dustproducing regions, can affect both the present-day simulation and the response to climate change forcing scenarios.
\end{abstract}

\section{Introduction}

The term "Earth System processes", as used in climate modelling, generally refers to the set of equations describing physical, chemical and biological processes within and between the atmosphere, ocean, cryosphere, and the terrestrial and marine biosphere. There is no strict definition of which processes at what level of complexity are required before a climate model becomes an Earth System Model (Collins et al., 2011). However, typically the term "Earth System" is used for those models that at least include terrestrial and ocean carbon cycles.

The inclusion of Earth System components in a climate model allows both consistent calculation of the impacts of climate change on atmospheric composition or ecosystems and the incorporation of biogeochemical feedbacks which can be negative (damping the sensitivity of the climate to external forcing, e.g. Charlson et al., 1987), or positive (amplifying the sensitivity, e.g. Cox et al., 2000; Friedlingstein et al., 2006). These feedbacks will either affect projections of future climate for a given forcing or, for a given desired climate outcome (such as limiting warming below $2 \mathrm{~K}$ above pre-industrial values), will affect the calculations of allowable emissions (e.g. Jones et al., 2006).

Earth System models tend to be driven by emissions of greenhouse gases (particularly $\mathrm{CO}_{2}$ ), rather than having concentrations specified. Adding Earth System components and processes increases the complexity of the model system. Many biogeochemical processes are less understood or constrained than their physical counterparts. Hence the model spread in future projections is considerably larger, and better represents the true uncertainty of the future evolution of 
climate. Booth et al. (2012) found that the spread in predicted temperatures due to uncertainty in just the carbon cycle modelling was comparable to the spread due to uncertainty in all the physical parameters.

However, the increased complexity can also result in larger and/or more numerous systematic biases in models. The growth of systematic errors in General Circulation Models (GCMs) remains one of the central problems in providing accurate projections of climate change for the next 50 to $100 \mathrm{yr}$ (Randall et al., 2007). Although great advances in global modelling have been made in recent decades (Solomon et al., 2007), there are still large uncertainties in many processes such as clouds, convection and coupling to the ocean and the land surface (e.g. Cubasch et al., 2001; Koster et al., 2004). It is not clear, therefore, to what extent climate projections are improved by the additional complexity of including Earth System process when the resulting changes in systematic biases are taken into account. As noted by Hurrell et al. (2009), given relatively large systematic errors in models, the additional feedbacks from more interactive components in Earth System models clearly increase the uncertainty in the magnitude and nature of the climate changes projected in future scenario simulations.

The HadGEM2 model family (The HadGEM2 Development Team, 2011) is a suite of model configurations incorporating different levels of complexity but with a common physical framework. The HadGEM2 family includes atmosphere, ocean and sea-ice components, and Earth System components including the terrestrial and oceanic carbon cycles and atmospheric chemistry. The HadGEM2 Development Team (2011) showed consistency in the large-scale physical performance of these model configurations and in the overall improvement compared with the previous model version (HadGEM1).

Previous studies investigating the influence of land cover, including those which examine the uncertainty in presentday vegetation distribution (e.g. Feddema et al., 2005; McCarthy et al., 2012) and those which apply idealised changes (e.g. Bonan et al., 1992; Osborne et al., 2004; Swann et al., 2012), have demonstrated significant impacts on tropical climate from vegetation changes in both the tropics and the mid-latitudes. In this paper, we examine the influence of changes in land cover resulting from the interactive terrestrial carbon cycle in the HadGEM2 Earth System configuration (HadGEM2-ES) on the present-day simulation and future projections of the South Asian summer monsoon.

\section{Model integrations}

We make use of the following integrations:

- present-day (1980-2005) sections of historical coupled model runs, initialised in 1860 after spin-up of a preindustrial control (the method of spin-up is described in Collins et al., 2011) and run through the 20th century;
- atmosphere-only runs for the same period forced with observed sea surface temperatures (SSTs) and sea ice;

- timeslice experiments where the atmosphere component is forced with $\mathrm{CO}_{2}$ and trace gases for the year 2100 based on the RCP8.5 scenario of the Fifth Coupled Model Intercomparison Project (CMIP5; Taylor et al., 2012), and with SSTs obtained by applying the difference between c.2100 SSTs from the HadGEM2ES RCP8.5 scenario run and c.1990 SSTs from the HadGEM2-ES historical run (using $30 \mathrm{yr}$ means) to the present-day monthly-varying observed SSTs from 1980-2005.

The experimental design and forcing datasets are as specified by CMIP5 and are detailed in Taylor et al. (2012).

The model configurations used are members of the HadGEM2 family as described by The HadGEM2 Development Team (2011). The atmosphere-only configuration, HadGEM2-A, and the coupled atmosphere-ocean configuration, HadGEM2-AO, are forced by prescribed land cover and vegetation types from the International Geophysical Biophysical Programme (IGBP; Loveland et al., 2000) with a prescribed seasonally-varying leaf area index (LAI) based on Moderate Resolution Imaging Spectroradiometer (MODIS) Terra Collection 5 monthly LAI datasets. Historical land use change information and projected future land use changes based on CMIP5 Representative Concentration Pathway (RCP) scenarios, provided to CMIP5 by the Landuse Harmonization team (Hurtt et al., 2011), were applied by Baek et al. (2012) to the IGBP land cover data in order to prescribe time-varying land cover fields for HadGEM2-AO and HadGEM2-A, and these were also used in our timeslice experiments.

In the HadGEM2-CCS and HadGEM2-ES configurations, the Top-down Representation of Interactive Foliage and Flora Including Dynamics (TRIFFID) dynamic vegetation model (Cox, 2001) is used to simulate the land cover changes from the pre-industrial control period through the presentday and into the future following the CMIP5 RCP scenarios, and land use changes from Hurtt et al. (2011) are applied as disturbances (see Jones et al., 2011 for more details). The HadGEM2-CCS configuration includes terrestrial and oceanic carbon cycle components and a verticallyextended atmosphere up to $85 \mathrm{~km}$ (compared with $40 \mathrm{~km}$ for the other configurations). HadGEM2-ES includes a tropospheric chemistry component in addition to the terrestrial and oceanic carbon cycle components (see The HadGEM2 Development Team, 2011 for more details).

\section{Climatology of the South Asian summer monsoon in the HadGEM2 family}

We first examine the climatology of the South Asian summer monsoon in the HadGEM2 family members. Typical 

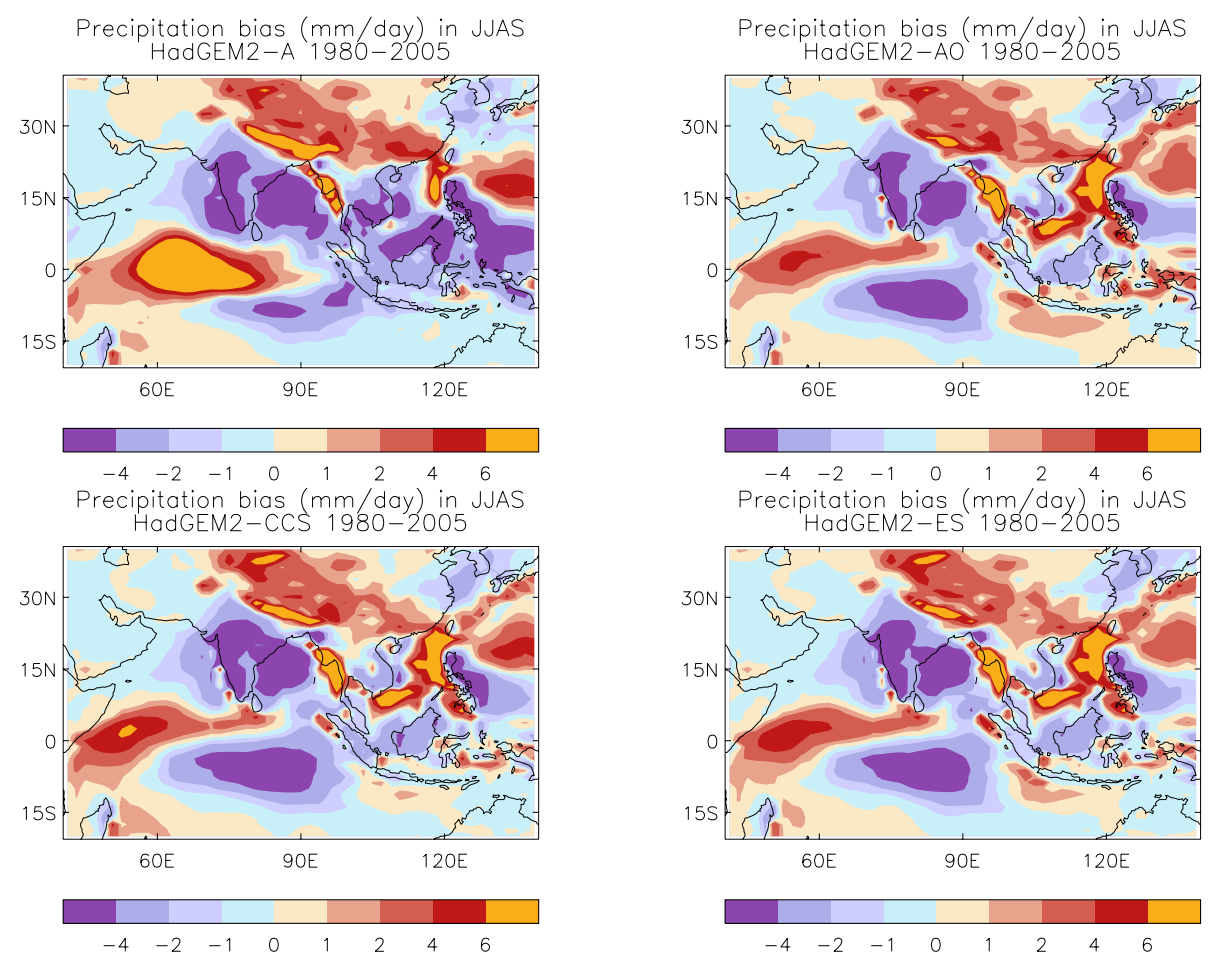

Fig. 1. Precipitation $\left(\mathrm{mm} \mathrm{day}^{-1}\right.$ ) in June-September (JJAS) difference from observed (Climate Prediction Center - CPC; Merged Analysis of Precipitation - CMAP/O; Xie and Arkin, 1997). -A: atmosphere-only; -AO: coupled; -CCS: coupled, carbon cycle, stratosphere; -ES: coupled, carbon cycle, chemistry.

monsoon systematic errors in the previous climate configuration, HadGEM1, were described by Ringer et al. (2006) and include excessive rainfall over the equatorial Indian Ocean and the Himalayan foothills and underestimation of rainfall over the Indian peninsula. These biases were reduced in the HadGEM 2 configuration through the seamless modelling approach (Martin et al., 2010), although their basic pattern still remains.

Figures 1 and 2 show that the different family members share similar systematic biases in winds and rainfall. However, the coupled configurations, which include an interactive ocean component (HadGEM2-AO, HadGEM2-CCS and HadGEM2-ES), differ from the atmosphere-only configuration, HadGEM2-A, particularly in the magnitude and location of the equatorial Indian Ocean rainfall bias. This is due to a compensating decrease in the SST in this region as a response to the excessive rainfall (Levine and Turner, 2012).

The coupled configurations show reduced anomalous convergence into this bias region compared with HadGEM2-A, and there is an associated increase in convergence along the western Indian peninsula, reducing the anticyclonic bias over this region. In spite of this, however, only HadGEM2-AO shows a reduced rainfall bias over the Indian peninsula compared with HadGEM2-A, while the CCS and ES configurations show similar or even larger biases.
Figure 3 shows the seasonal cycle of rainfall from the four configurations. The amplitude of the seasonal cycle of Indian rainfall is underestimated, particularly by HadGEM2-A. The coupled configurations exhibit a delayed onset due to an Arabian Sea SST bias in spring (Levine and Turner, 2012), but have better peak rainfall. The latter is associated with a negative feedback between the rainfall and SSTs in the equatorial Indian Ocean region, with the reduced rainfall bias and colder SSTs both promoting increased rainfall over India. As suggested by the seasonal mean rainfall biases in Fig. 1, the CCS and ES configurations show reduced rainfall amounts over the Indian peninsula compared with HadGEM2-AO.

The ES and CCS configurations, which both include the terrestrial carbon cycle, have much more bare soil over India and the Sahel than the A or AO configurations, replacing grass, shrubs and broadleaf trees (Fig. 4). This is a result of persistent underestimation of rainfall over these regions during the pre-industrial control and historical runs, and illustrates the feedbacks that can occur between model systematic biases. Other differences in vegetation include a change from trees and grasses to shrubs in northeastern Eurasia, increased fractions of needleleaf trees at the expense of grass and bare soil over the Tibetan region, and a replacement of grasses with bare soil over Australia. These differences are discussed further in Collins et al. (2011). 

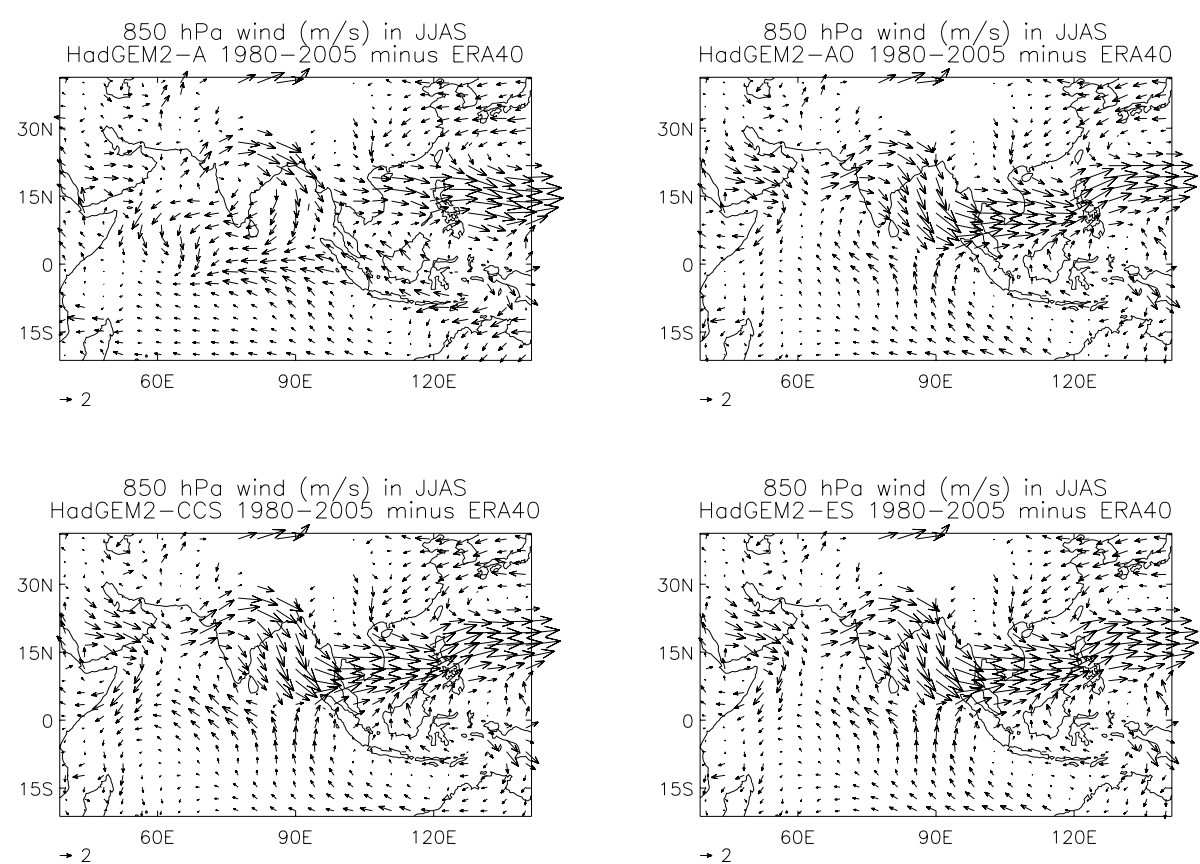

Fig. 2. As Fig. 1 but for horizontal wind at $850 \mathrm{hPa}$ compared with ERA40 reanalyses (Uppala et al., 2005).

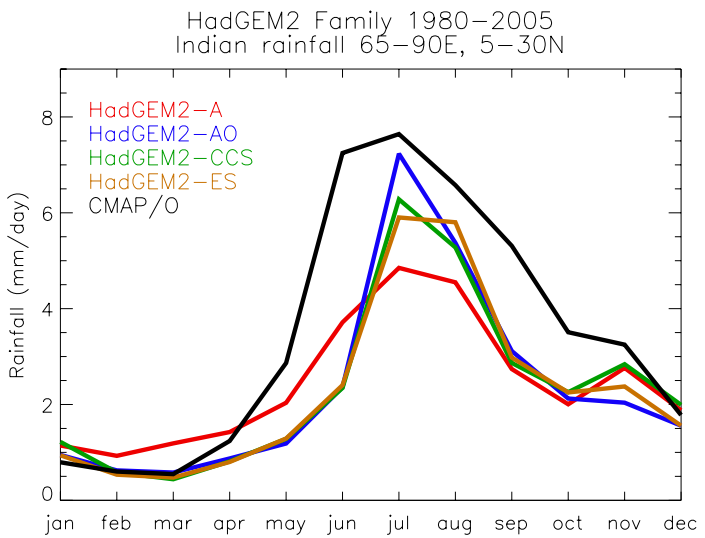

Fig. 3. Seasonal cycle of rainfall over the Indian region $\left(65-90^{\circ} \mathrm{E}\right.$, $5-30^{\circ} \mathrm{N}$ ) in the HadGEM2 model family, compared with CMAP/O.

Over India, the increased bare soil is associated with smaller latent heat fluxes in ES and CCS in summer (not shown) as evaporation and transpiration from vegetation is reduced. This may contribute to the larger Indian rainfall bias in ES and CCS. However, the latent heat flux is affected by the land cover type (which affects evaporation), the wind speed (which is related to the monsoon circulation as a whole, which itself is related to the surface temperature distribution and differs markedly between the coupled and atmosphere-only configurations) and the soil moisture, and the latter is also related to the precipitation. Thus, understanding the processes by which the precipitation is affected is not straightforward.

\section{Sensitivity experiments}

In order to shed light on the role of the vegetation distribution in the differences in monsoon rainfall between these configurations, additional experiments have been run with the atmosphere-only configuration, HadGEM2-A. Each is based on the standard Atmospheric Model Intercomparison Project (AMIP) setup as described in Taylor et al. (2012) and details of the baseline HadGEM2-A configuration are given in The HadGEM2 Development Team (2011). The details of each sensitivity experiment, along with the results, are described in the following sub-sections.

\subsection{Using land cover from the ES configuration}

In this experiment, the monthly mean land cover information from years 1980-2005 of the HadGEM2-ES historical run is used in HadGEM2-A in place of the standard land cover distribution as described in Sect. 2. Therefore, the variations in land cover with time during this period in HadGEM2-ES are experienced by HadGEM2-A, but there is no interactive terrestrial carbon cycle and no feedbacks on the land cover. We refer to this experiment as "HadGEM2-AE".

Comparison of the seasonal mean precipitation from HadGEM2-A and HadGEM2-AE shows a marked decrease in rainfall over the Indian region in the sensitivity experiment, while precipitation increases over the South China Sea and the western Pacific (Fig. 5). These changes are similar in pattern to those seen between HadGEM2-ES and -AO (Fig. 5d) but they are considerably larger in the atmosphereonly experiments. In addition, the HadGEM2-AE experiment 
Difference in Fractions of Plant Functional Types in JJAS
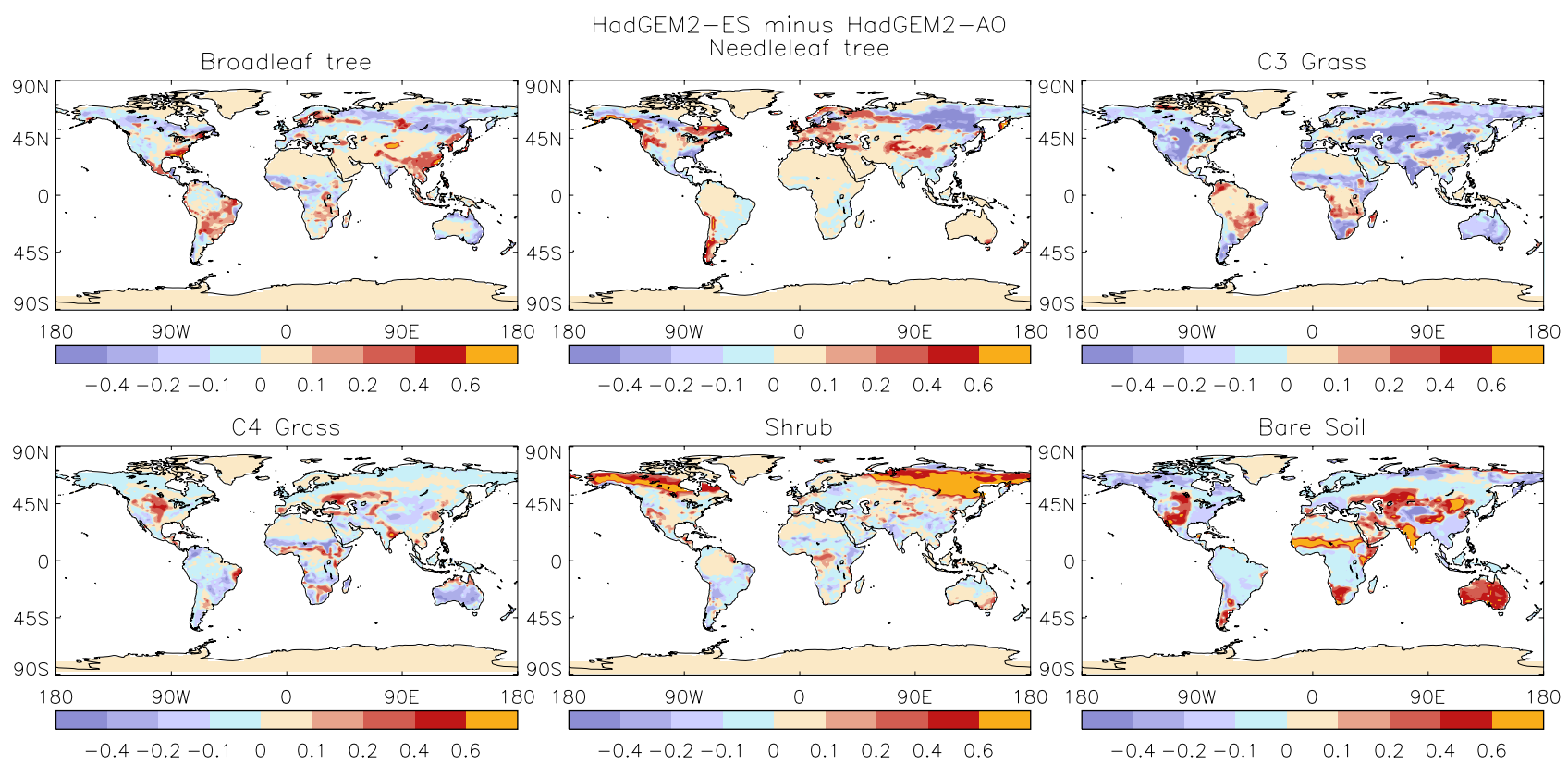

Fig. 4. Differences in present-day (1980-2005) land cover type between HadGEM2-ES and HadGEM2-AO.
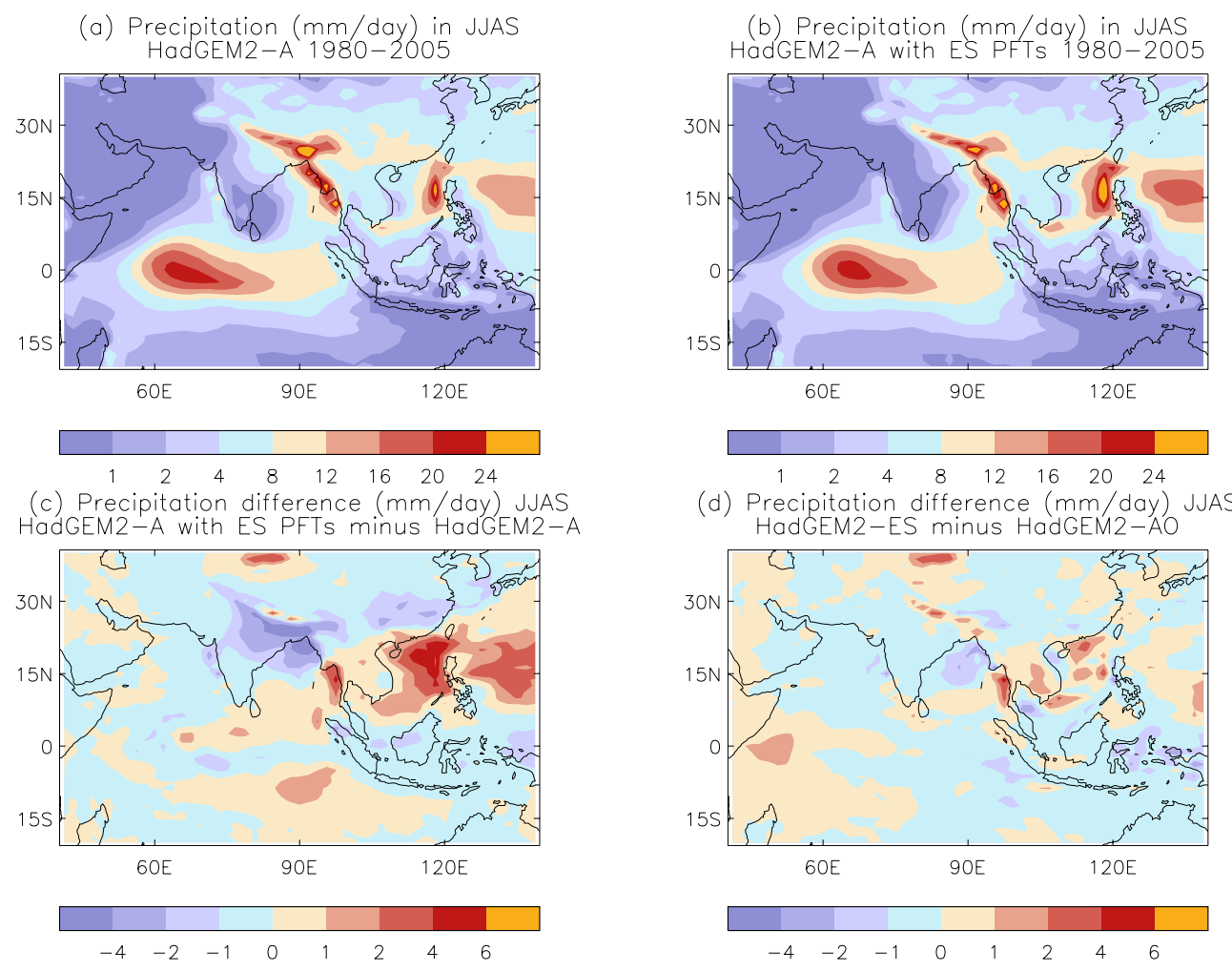

Fig. 5. Precipitation in JJAS (mm day ${ }^{-1}$ ) in (a) HadGEM2-A and (b) the HadGEM2-AE experiment, and differences (c) HadGEM2-AE minus HadGEM2-A and (d) HadGEM2-ES minus HadGEM2-AO. 


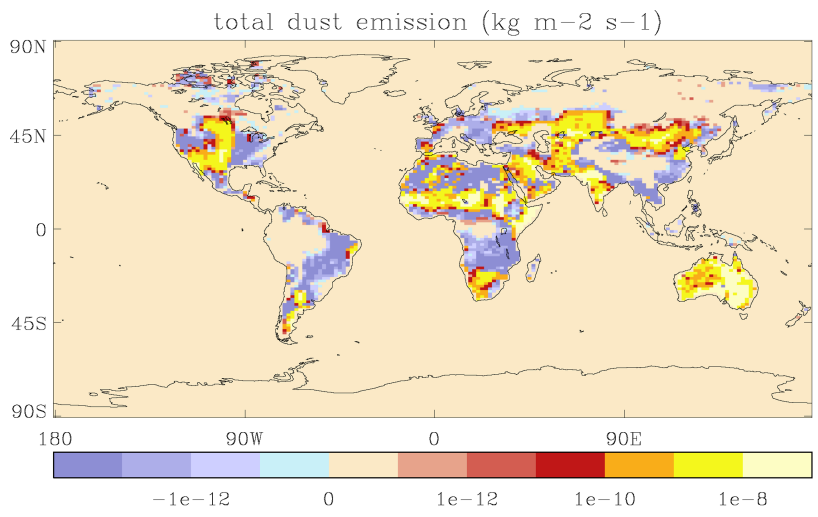

total dust deposition ( $\mathrm{kg} \mathrm{m}-2 \mathrm{~s}-1)$

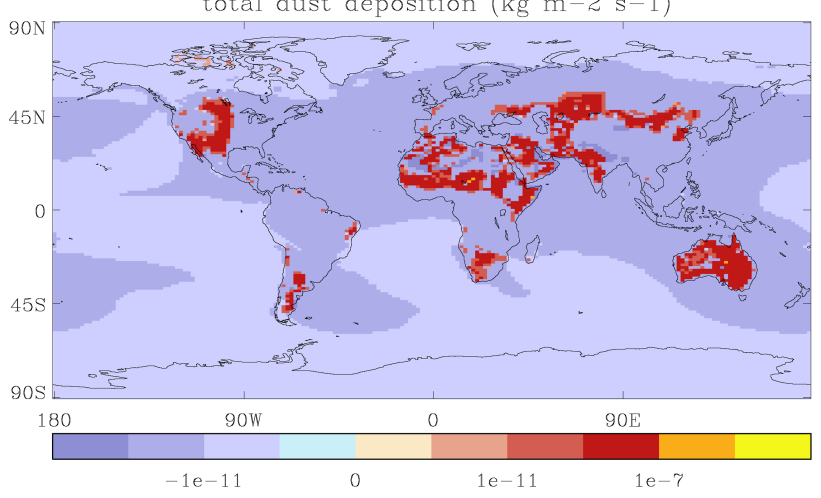

total column total dust mass (kgm-2)

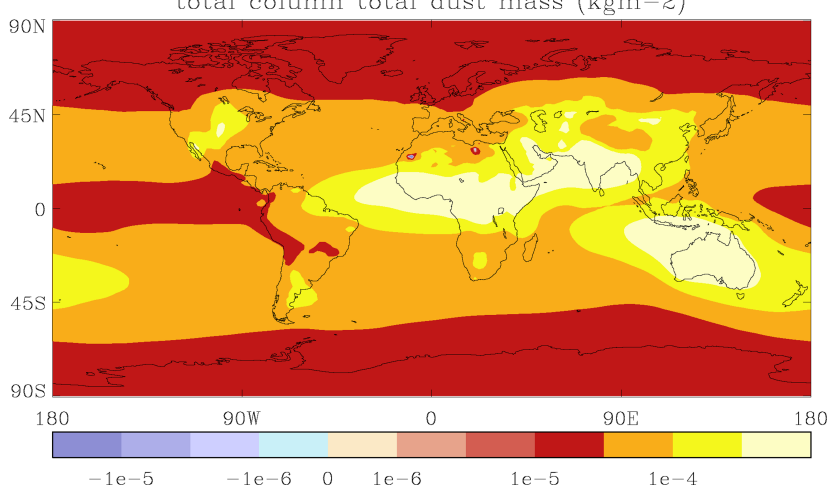

Fig. 6. Change in annual climatology of dust emission, deposition and total column dust mass between HadGEM2-AE and HadGEM2-A simulations (with and without land cover from HadGEM2-ES). Note the non-linear scale.

shows a large increase in dust, which is generated as a result of the additional fraction of bare soil in key tropical regions such as India, Saudi Arabia, Africa and Australia (Fig. 6). A similar increase in total column dust occurs between HadGEM2-ES and HadGEM2-AO ${ }^{1}$ (not shown).

\footnotetext{
${ }^{1}$ Note that different dust tuning parameters are applied in HadGEM2-A compared with those used in the coupled HadGEM2 configurations, resulting in different (larger) total amounts of dust emission, deposition and total dust mass; however, the relative changes between the HadGEM2-AE and HadGEM2-A experiments and the $\mathrm{ES}$ and $\mathrm{AO}$ historical runs are comparable.
}

This affects the clear-sky radiative fluxes at the surface, particularly by increasing outgoing shortwave radiation at the top of the atmosphere and reducing the downward shortwave radiation at the surface (Fig. 7a and c). The outgoing longwave radiation at the top of the atmosphere is also reduced (Fig. 7b). These changes are largest over the Arabian Sea, India and the Bay of Bengal, although they are also apparent over West Africa and northern Australia.

The radiative effects of the dust act to cool the daytime maximum temperatures and warm the nighttime minimum temperatures. Since most of the convection over land is during the day (in the model) the impact on total rainfall may be significant. In order to test this hypothesis, we run an additional pair of experiments where the direct radiative effects of the dust are switched off. We find that there is indeed a substantial direct radiative impact on the monsoon rainfall of the additional dust generated as a response to the change in the vegetation distribution (Fig. 8a, b and d). With the original AMIP land cover distribution, the sensitivity is smaller because there is much less dust (Fig. 8c). The low level monsoon circulation (Fig. 9) is reduced in association with the change in radiative heating and precipitation.

The impact of increased dust loading on the Asian monsoon in our simulations is consistent with the "dimming" effect discussed by Ramanathan et al. (2005) and Lau and Kim (2006). While the influence of aerosols on the Asian monsoon simulation is not the focus of this paper, the significant impact of the changes in dust warrants further study, perhaps with more realistic dust loading. The role of aerosols in moderating the Asian summer monsoon rainfall and circulation has been the subject of many recent studies, and it is still unclear whether aerosols could strengthen or weaken the monsoon (Nigam and Bollasina, 2010; Kuhlmann and Quass, 2010 , and references therein). Our results suggest that the errors in the land cover distribution which arise through the interaction between the dynamic vegetation and existing systematic biases in monsoon rainfall could add to this uncertainty via feedbacks on the dust loading of the atmosphere. While this sensitivity may be exaggerated in this particular model configuration through its specific combination of physical parametrisations, it highlights how studies of important feedbacks can be complicated by such combinations of systematic error.

\subsection{Impacts of changes in land cover with no dust radiative feedback}

We have demonstrated that the errors in the land cover distribution, which arise through the interaction between the dynamic vegetation and existing systematic biases in monsoon rainfall, can have a noticeable impact on the seasonal mean monsoon precipitation in South Asia. While the impacts on dust aerosol warrant further investigation in a separate study, for the remainder of this paper we seek to isolate more clearly 

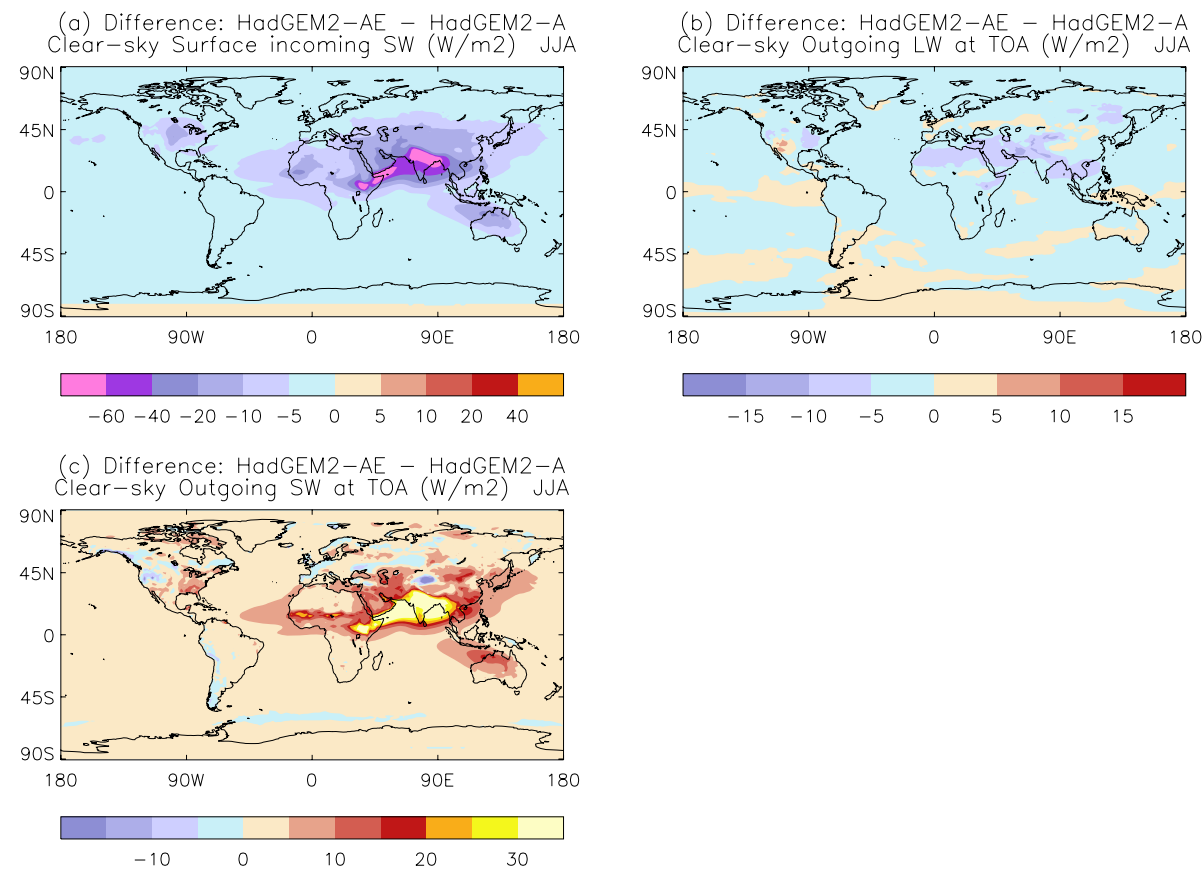

Fig. 7. Clear-sky radiative flux differences $\left(\mathrm{W} \mathrm{m}^{-2}\right.$ ) in JJA between HadGEM2-AE and HadGEM2-A runs: (a) surface incoming SW; (b) outgoing LW at TOA; (c) outgoing SW at TOA.
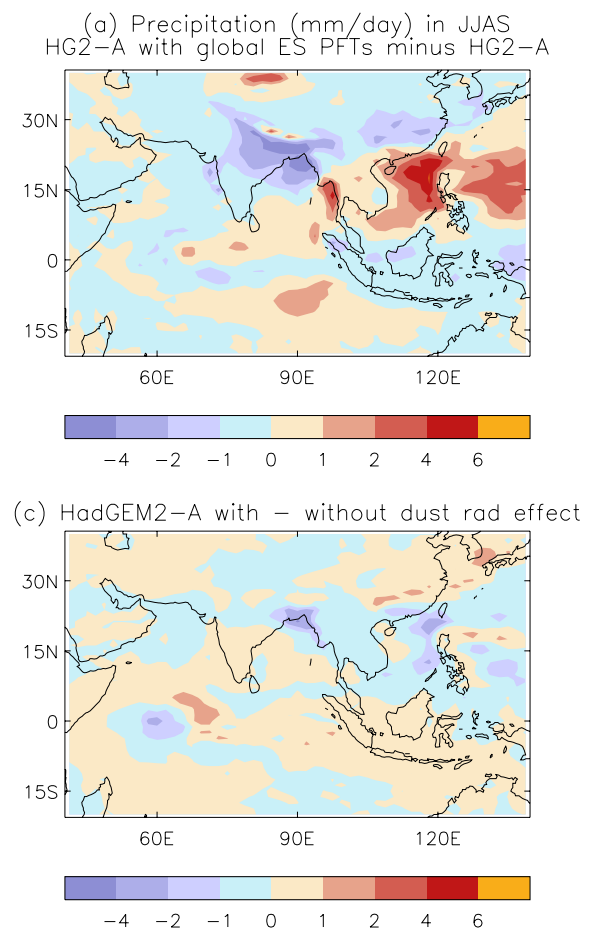

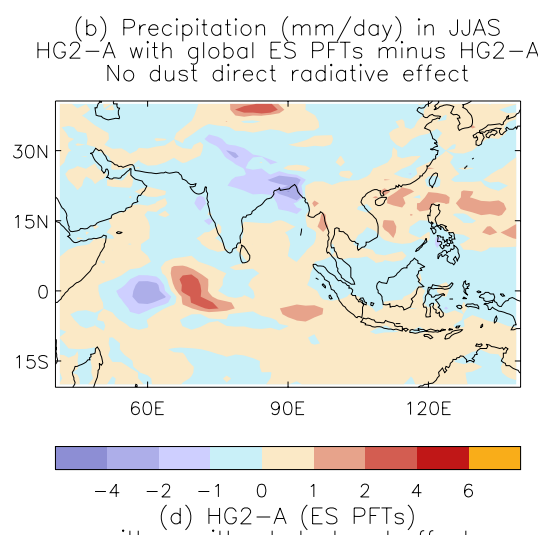

(d) HG2-A (ES PFTS)

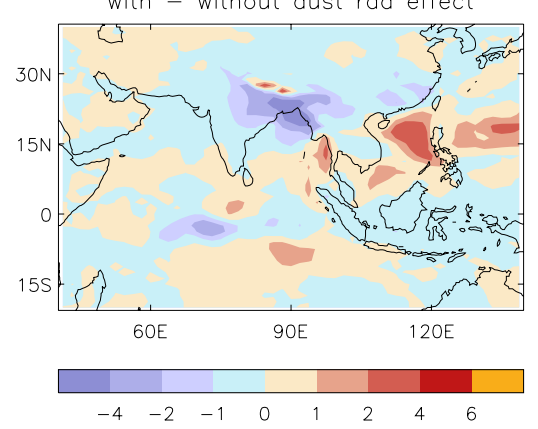

Fig. 8. Changes in JJAS precipitation between (a) HadGEM2-A and -AE experiments, (b) as (a) but without the direct radiative effect of dust, (c) HadGEM2-A with-without direct radiative effect of dust, (d) as (c) but for HadGEM2-AE. 

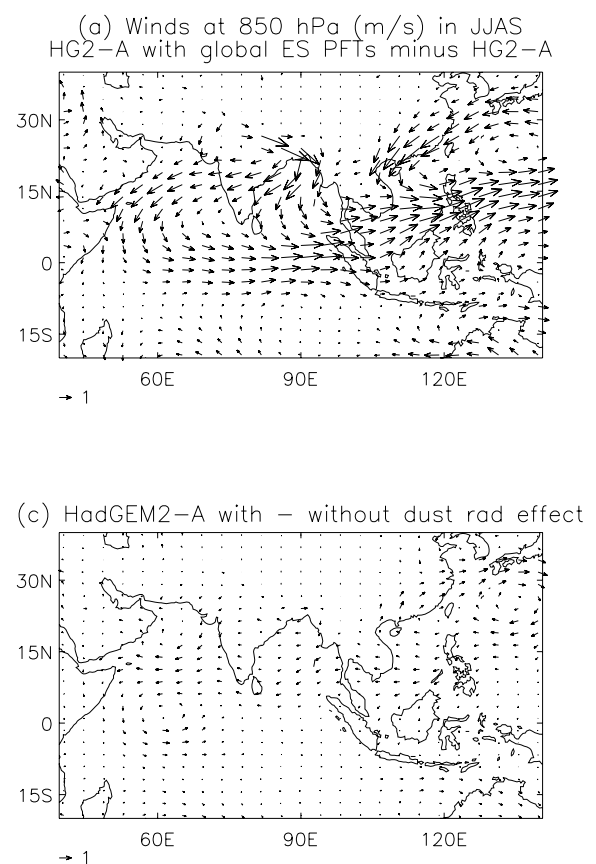

Fig. 9. As Fig. 8 but for horizontal wind at $850 \mathrm{hPa}$.

the impacts of the changes in the vegetation distribution by removing the direct radiative effects of dust.

McCarthy et al. (2012) examined the impact on the HadCM3 model (Pope et al., 2000; Gordon et al., 2000) of applying vegetation cover from different land cover datasets and from an earlier version of the TRIFFID dynamic global vegetation model (Cox, 2001) than that which is used in HadGEM2-ES and -CCS. They found a dynamical response of the South Asian summer monsoon resulting from changes in mid-latitude temperatures and snow albedo feedbacks, consistent with previous studies (e.g. Douville and Royer, 1996; Turner and Slingo, 2011). It is interesting, therefore, to examine our own sensitivity experiments with this more recent model configuration in order to determine whether similar responses are present.

We focus on differences between the simulations in the boreal spring and summer seasons, since these are most relevant to the changes in the South Asian summer monsoon. In a similar manner to McCarthy et al. (2012), we find the largest impacts of the change in the land cover distribution occur in boreal spring (compare Figs. 10 and 11). There is a reduced sensible heat flux over northeastern Eurasia (Fig. 10c) and cooling in the near-surface temperatures of more than $5 \mathrm{~K}$ across a wide region (not shown). This is driven by large increases in outgoing shortwave radiation (Fig. 10b), which outweigh reductions in outgoing longwave radiation (Fig. 10a). These changes are related to increased snow cover over this region in boreal spring (not shown) which, as discussed by McCarthy et al. (2012), is associated with the change in vegetation type from trees (particularly needleleaf trees) to shrubs
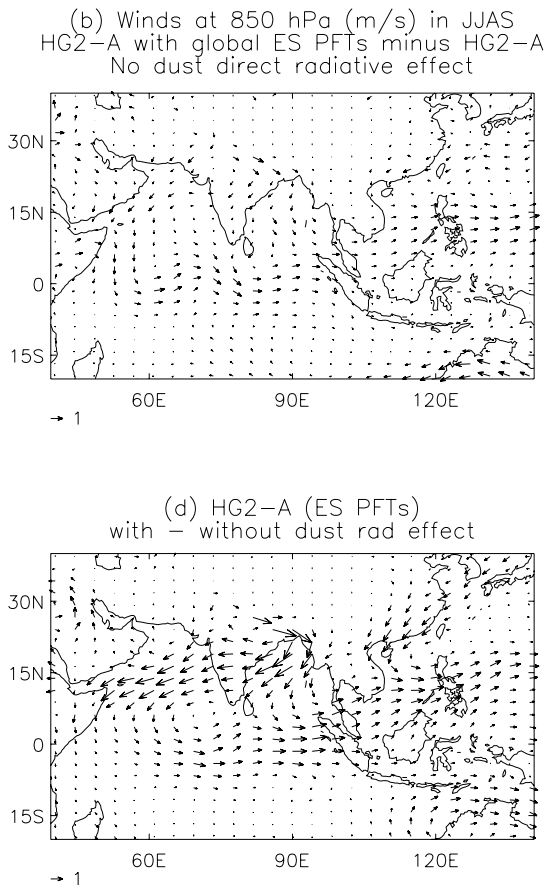

(Fig. 4). In contrast, increases in needleleaf tree fractions at the expense of grass and bare soil over the Tibetan region are associated with reduced snow cover and warmer temperatures (larger sensible heat fluxes; Fig. 10c). This pattern of snow cover anomalies is consistent with that described by Turner and Slingo (2011) for the HadCM3 model and for other model studies referenced in that paper.

Xavier et al. (2007) showed that the monsoon onset and amplitude are related to the change in sign from negative to positive of the tropospheric temperature gradient between the Indian Ocean and the Asian land mass. Previous studies such as that of Turner and Slingo (2011) have indicated that the cooling associated with increased Eurasian snow cover, such as that found in our experiments (and in those of McCarthy et al., 2012 in response to the change in land cover), can be associated with weakening of the Tibetan anticyclone and weaker upper level easterly winds over the monsoon region, as a result of the reduction in the tropospheric meridional temperature gradient. However, Turner and Slingo (2011) noted that this response could be reversed if the opposing changes over the Himalayas and Tibetan Plateau were dominant. Figures 10 and 11 suggest that the cooling/warming in these two regions are of similar magnitude and may cancel. We find that the dynamical response is to broaden and weaken the upper-level subtropical jet slightly, but that the changes are indeed relatively small (Fig. 12). This is consistent with the small changes in low level monsoon winds and precipitation shown in Sect. 4.1. 

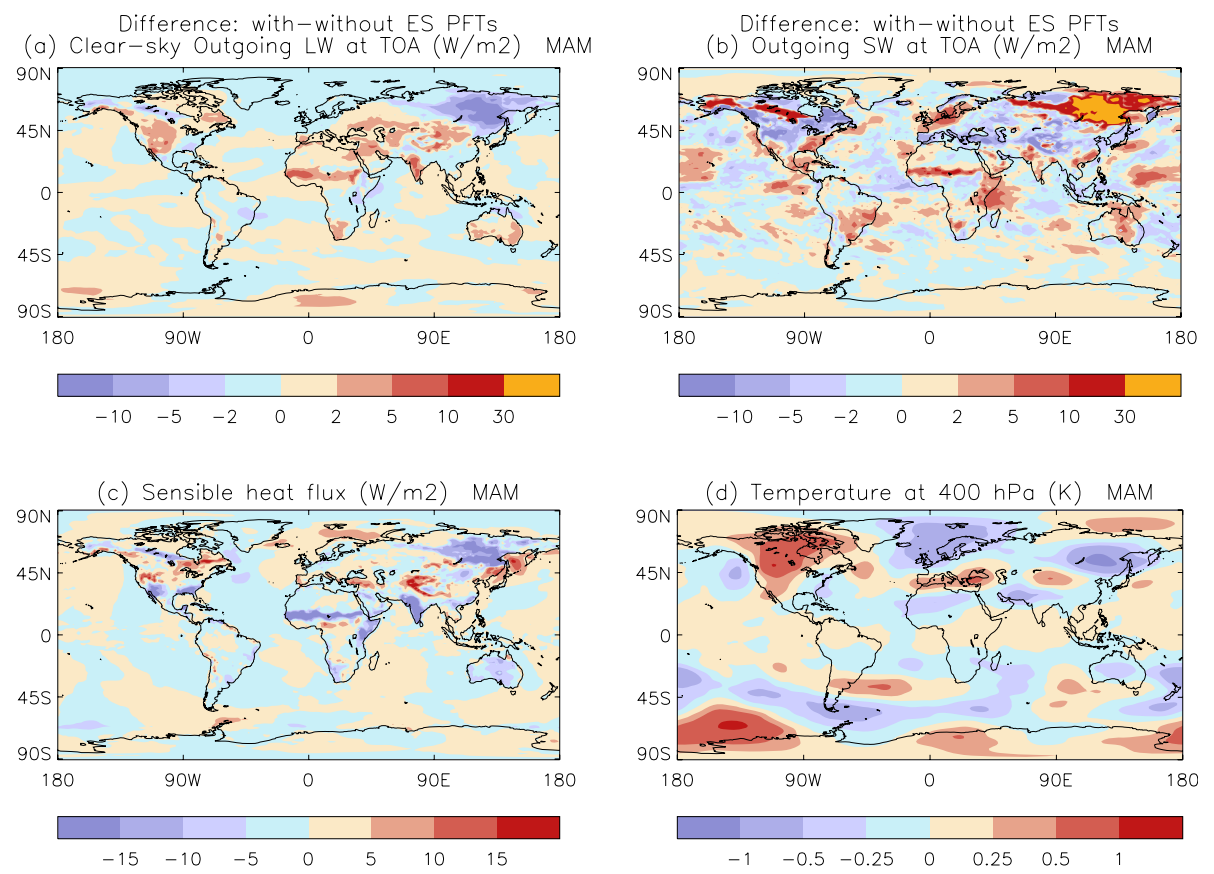

Fig. 10. Global changes in March, April, May (MAM) between experiments with and without land cover from HadGEM2-ES, and with no dust radiative effects: (a) clear-sky outgoing longwave radiation at top-of-atmosphere (TOA); (b) outgoing shortwave radiation at TOA; (c) surface sensible heat flux; (d) temperature at $400 \mathrm{hPa}$.
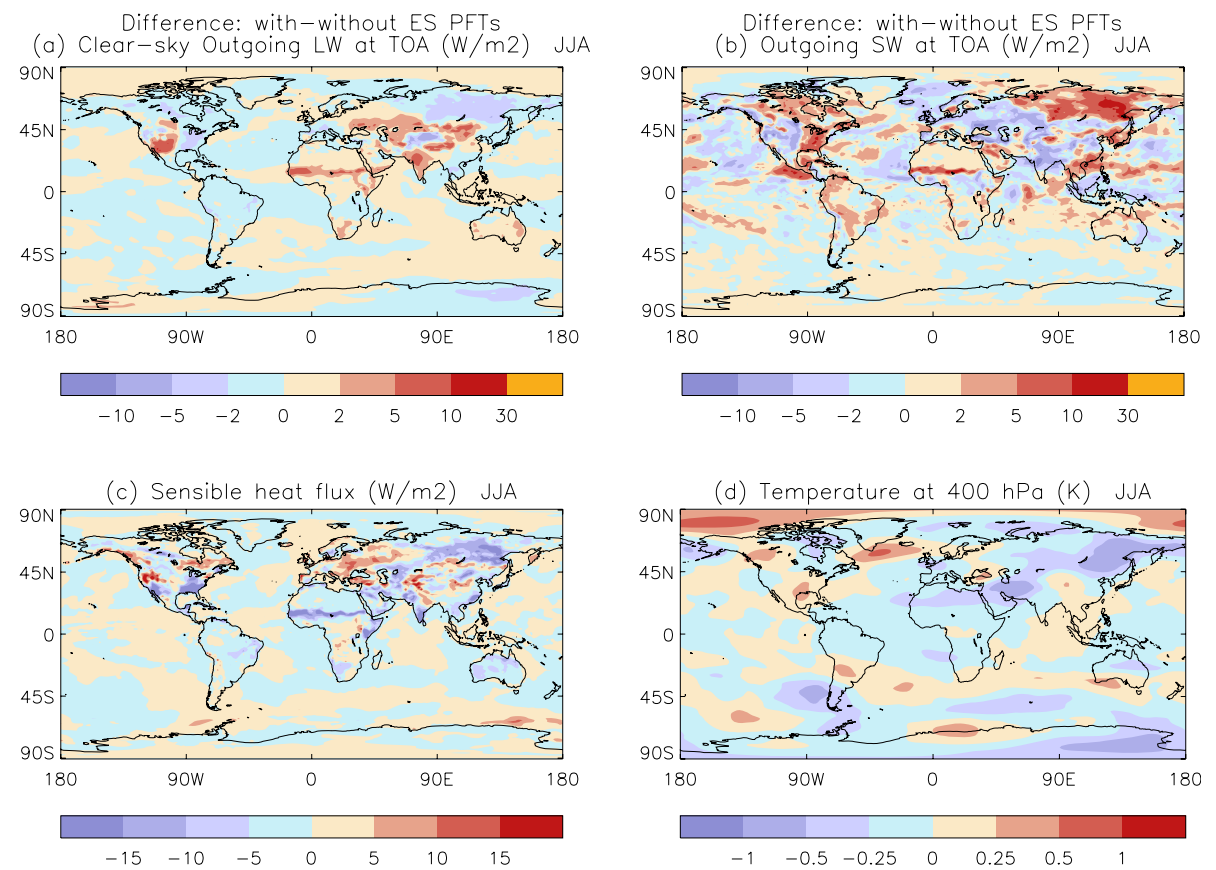

Fig. 11. As Fig. 10 but for June, July, August (JJA).

\subsection{Future experiments}

The results discussed above, along with previous studies such as those of McCarthy et al. (2012), suggest that the interaction between dynamic vegetation and model systematic

biases, such as regional rainfall, may affect the simulation of present-day climate. It follows that the response to climate change may also be affected. This is potentially an area for concern, given the increasing number of Earth System models that include dynamic vegetation schemes. 

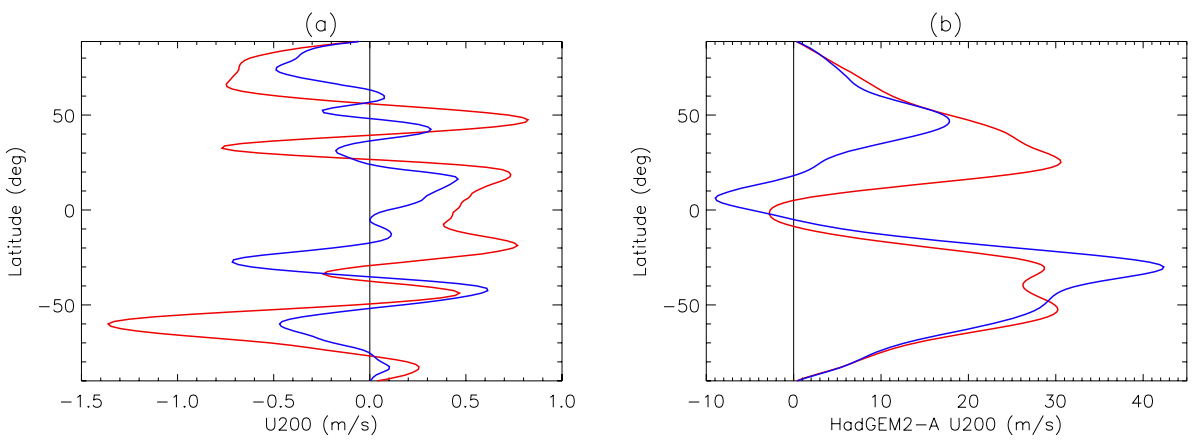

Fig. 12. Zonal mean horizontal westerly wind at $200 \mathrm{hPa}\left(\mathrm{m} \mathrm{s}^{-1}\right)$ in MAM (red) and JJA (blue): (a) differences between runs with and without land cover from HadGEM2-ES (no dust radiative effects); (b) actual wind in HadGEM2-A (no dust radiative effects).
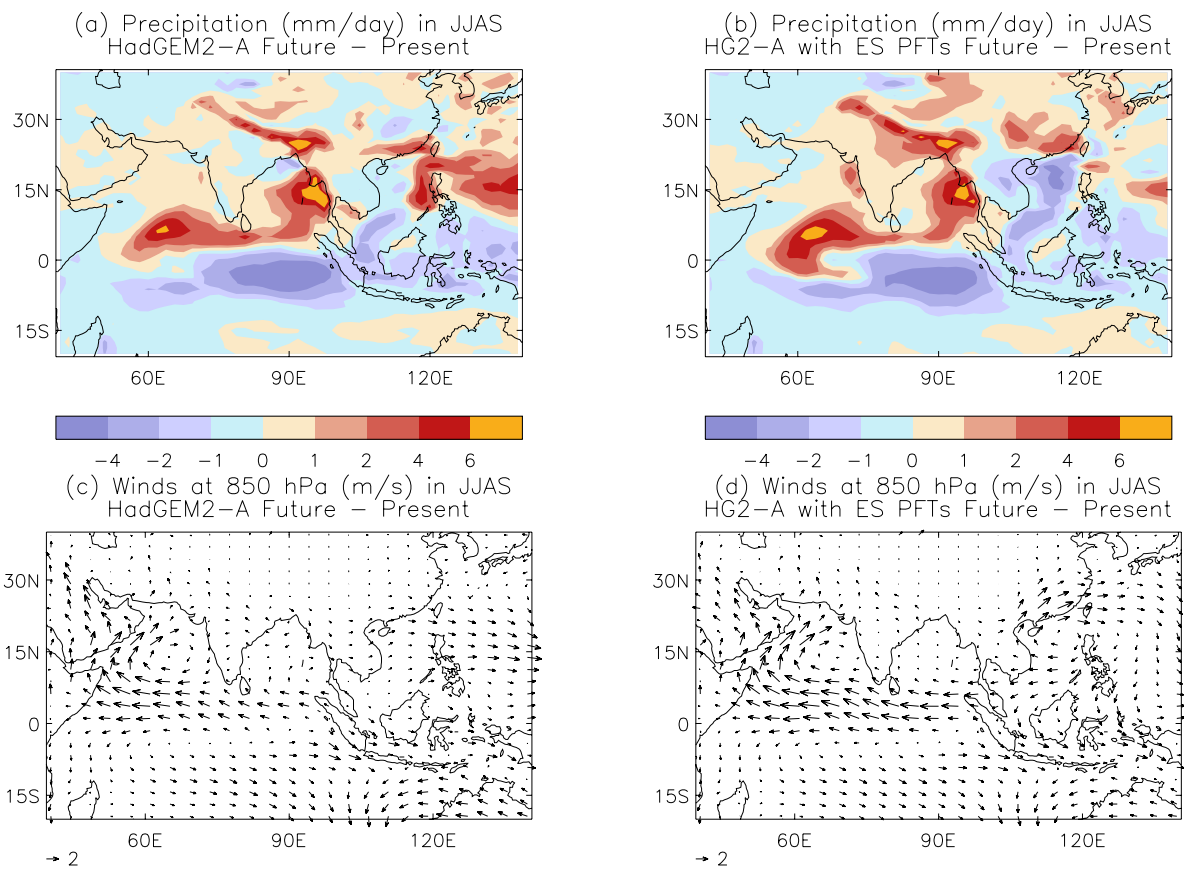

Fig. 13. Change in JJAS mean precipitation $\left(\mathrm{mm}^{-1}{ }^{-1}\right)$ between future timeslice and present-day HadGEM2-A experiments, with and without land cover from HadGEM2-ES.

In order to investigate the role of the different vegetation distributions in the climate change response, with and without the feedbacks on the dust loading, we carry out future timeslice experiments as described in Sect. 2. Four 26-yr runs are carried out, with and without the land cover from HadGEM2-ES, and with/without the direct effects of mineral dust included. Each is compared with its present-day counterpart.

Increases in monsoon rainfall are seen in the future timeslice experiments over the area spanning the Arabian Sea, India and the Bay of Bengal (Fig. 13a and b). The low-level flow over the Arabian Sea is directed more towards the north of India, while the westerly flow across the southern Arabian Sea is weakened somewhat (Fig. 13c and d). This is consistent with the changes seen in the full HadGEM2-ES and -AO RCP8.5 experiments as well as in idealised climate change experiments where $4 \mathrm{xCO}_{2}$ is applied as a step change (not shown) It is also consistent with the findings in CMIP3 of enhanced moisture availability dominating any weakening of the monsoon flow that arises through a weakening of the tropospheric meridional temperature gradient (Meehl et al., 2007).

The future-present differences are similar in the experiments with and without the ES land cover. However, there is an indication of larger increases in rainfall over the Indian region when the ES land cover is used in the timeslice experiments, and this appears to be associated with an additional increase (or reduced decrease) in convergence over the Indian peninsula. These differences are illustrated better by the "double-difference" plots in Fig. 14a and c. 

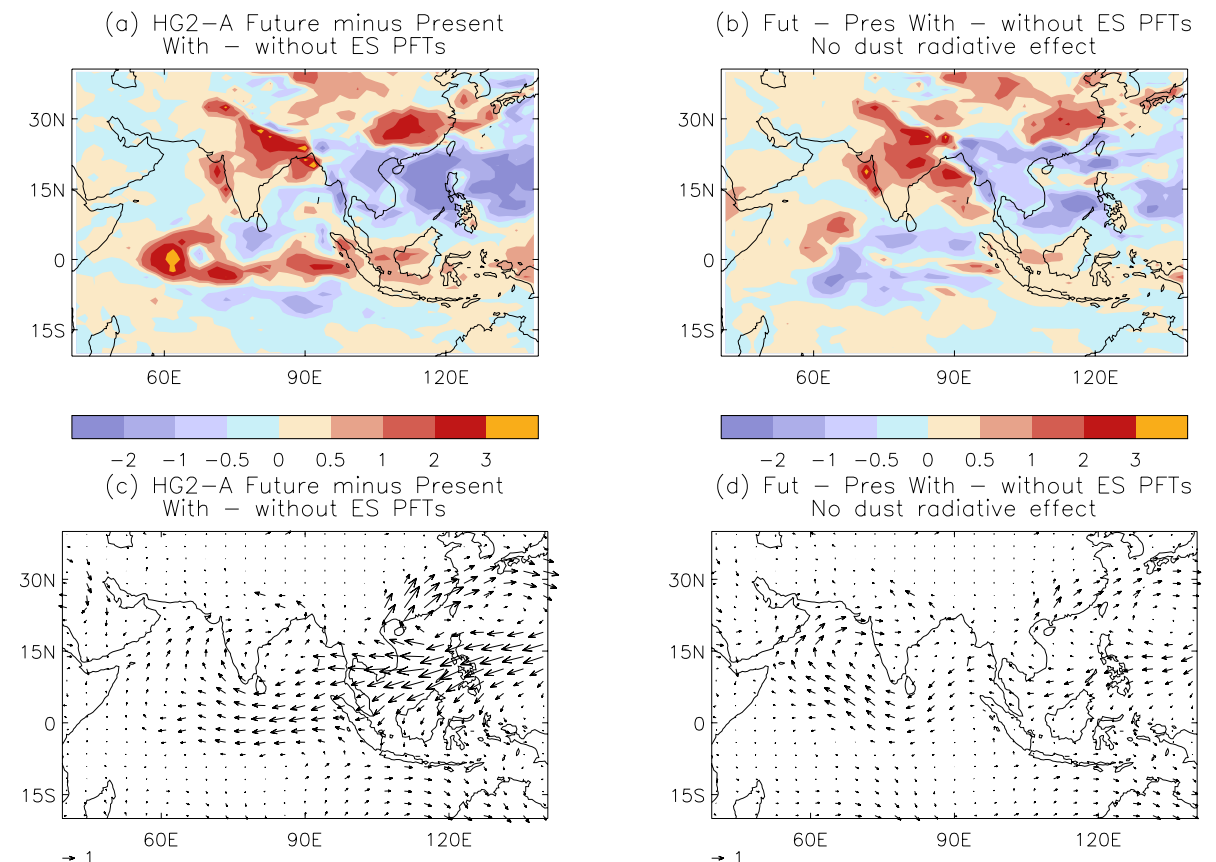

Fig. 14. Difference in the projected future-present changes in seasonal mean rainfall and horizontal wind at $850 \mathrm{hPa}$ between runs with and without land cover taken from HadGEM-ES RCP8.5 experiments: (a) and (c) with, and (b) and (d) without direct radiative effects of dust.
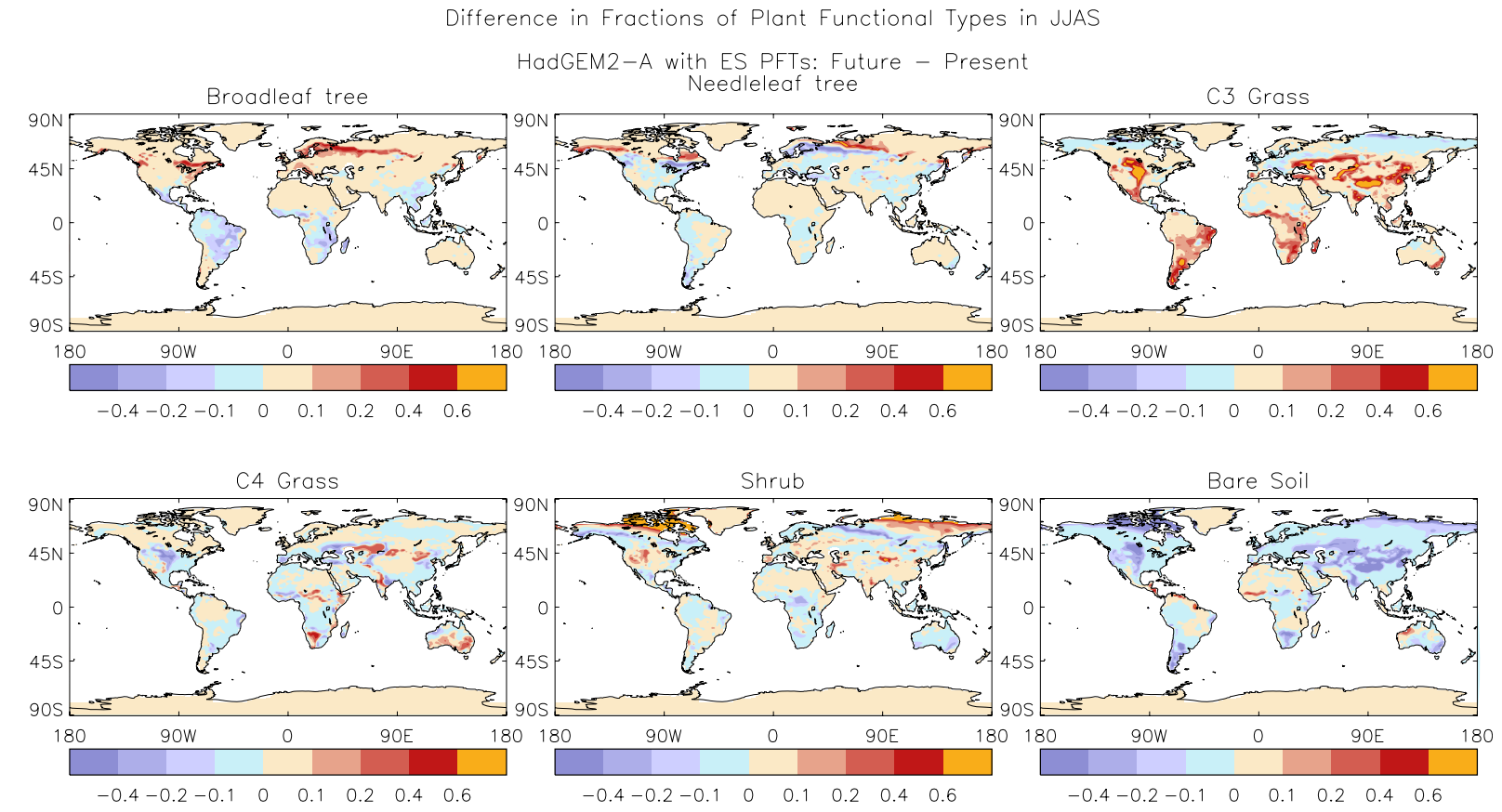

Fig. 15. Changes in land cover between c. 2100 and present-day as simulated by HadGEM2-ES in the CMIP5 RCP8.5 scenario and applied in HadGEM2-AE present and future timeslice experiments.

In the HadGEM2-ES RCP8.5 simulation, the vegetation responds to the increased future rainfall by reducing the bare soil extent and replacing this mainly with grasses, particularly over Asia. There is some increase in tree cover over northeastern Eurasia but there is also an increase in the fraction of shrub (Fig. 15). However, the extent of bare soil in dust-emitting regions is still excessive compared with HadGEM2-AO for the same time period, and there is little change in the dust load between future-present (not shown). 

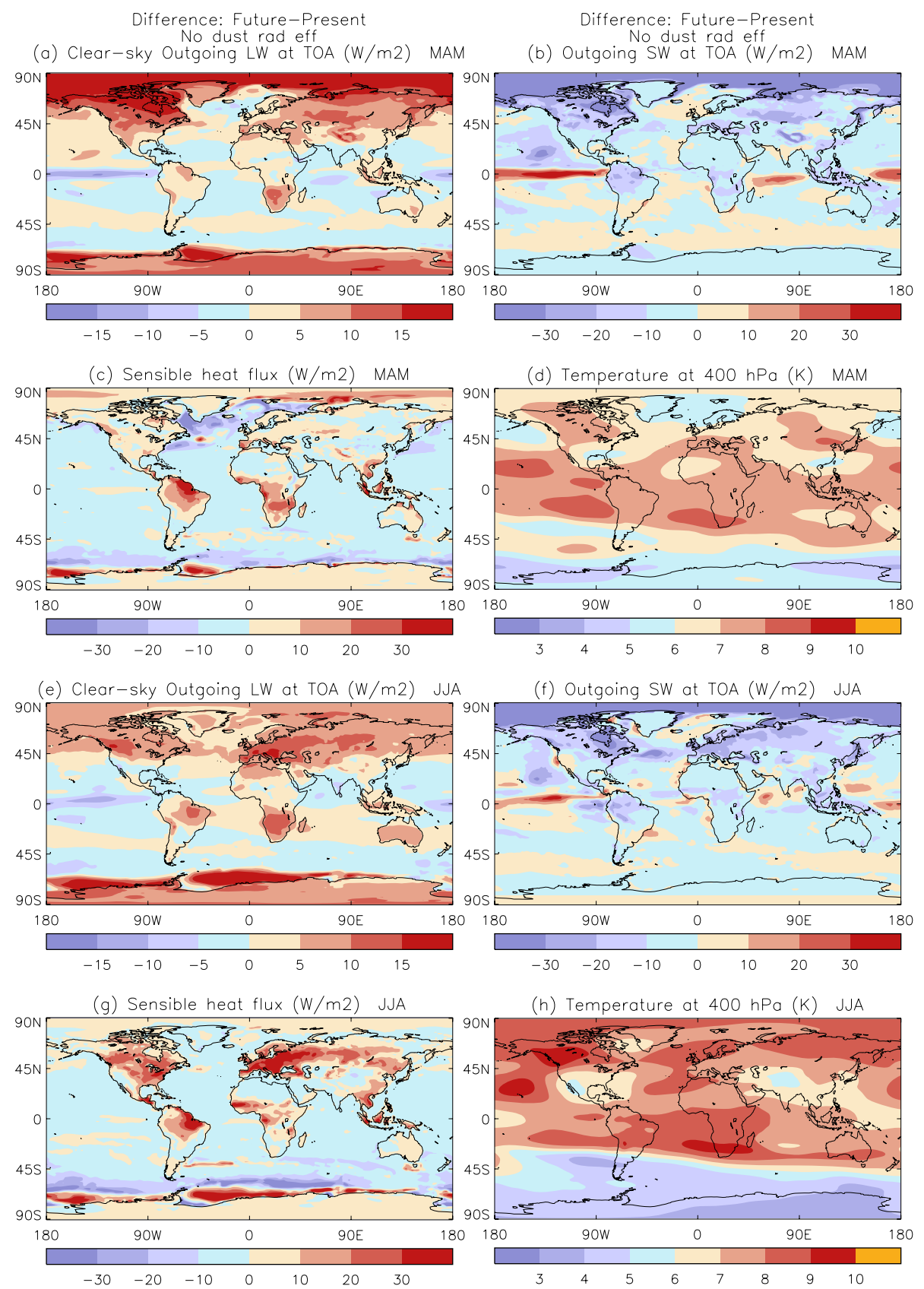

Fig. 16. Global differences between future timeslice and present-day simulations using HadGEM2-A (and no dust radiative effects): (a) clearsky outgoing longwave radiation at TOA; (b) outgoing shortwave radiation at TOA; (c) surface sensible heat flux; (d) temperature at $400 \mathrm{hPa}$, for MAM, and (e)-(h) similar for JJA.

Over the Indian peninsula, without the dust radiative effect there is a slightly larger increase in rainfall over and above that seen between future-present when the ES land cover distribution is used (Fig. 14b and d), although over the Indian region as a whole the effect is mixed. The impact of the dust is rather larger over the South China Sea and western Pacific where the double-difference plots (Fig. 14a and b) suggest that it is the dust radiative effect that drives the apparently smaller increase in rainfall in this eastern region between future-present when the ES vegetation distribution is used. As mentioned above, the role of the dust changes on the monsoon simulation in this region warrants separate study. We therefore investigate the impact of the different vegetation distributions on the future-present differences with the direct radiative effects of the dust removed.

The global changes between future-present show the overall warming of the northern hemisphere and equatorial region (Fig. 16a, d, e and h) accompanied by reduced outgoing 

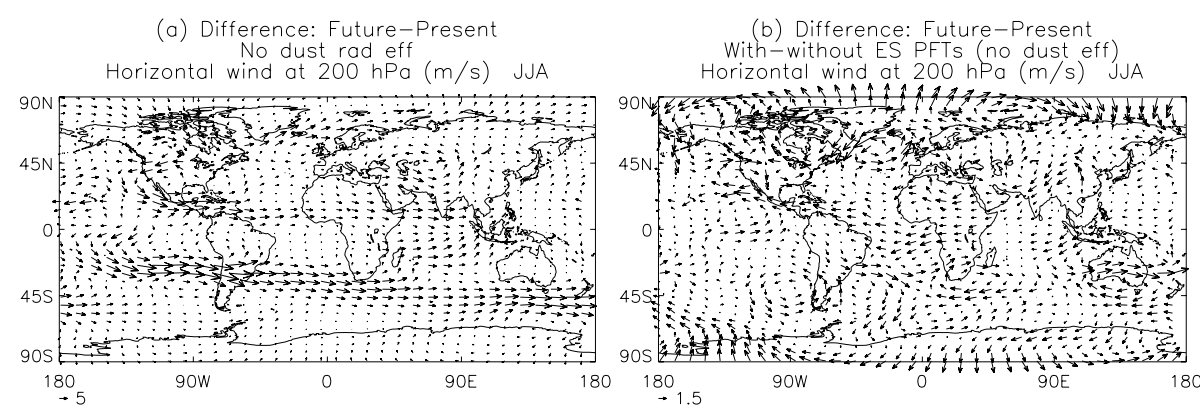

Fig. 17. Horizontal wind at $200 \mathrm{hPa}\left(\mathrm{m} \mathrm{s}^{-1}\right)$ : (a) future-present changes for HadGEM2-A; (b) the impact of the ES land cover on the future-present differences (with no dust radiative effects). Note different scales.

shortwave radiation (Fig. 16b and f) as the northern hemisphere sea ice melts and the snow cover decreases. The meridional tropospheric temperature gradient between the Indian Ocean and the Asian land mass decreases in spring and summer (Fig. 16d and h) and the Tibetan anticyclone weakens (Fig. 17a). This is counteracted somewhat, however, by the inclusion of the land cover distribution from HadGEM2-ES (Fig. 17b), which is associated with a larger warming over the northeastern Eurasian landmass in spring, which becomes widespread in summer (Fig. 18). This is related to a larger reduction in Eurasian snow cover between future-present with the ES land cover (not shown), which is associated with a larger decrease in outgoing shortwave radiation and warmer surface temperatures (larger surface sensible heat fluxes; Fig. 18). We find that these differences in the future-present changes are mainly due to the differences between the present-day simulations with and without the ES land cover, as there is more snow cover in the present-day HadGEM2-AE than HadGEM2-A (Sect. 4.2).

\section{Summary and conclusions}

In this study we have investigated the impact of using dynamic vegetation in a climate model on the South Asian summer monsoon climatology and its response to climate change. We have used the HadGEM2 model family, which includes members with and without dynamic vegetation and other Earth System processes, but has a common physical framework. This allows us to isolate the role of such processes in regional climate changes.

The members of the HadGEM2 model family share common systematic biases in monsoon rainfall and circulation. In particular, despite a realistic monsoon circulation, there is a persistent dry bias in rainfall over the Indian peninsula. When interactive vegetation is included, the persistent dry bias is associated with an increase in the bare soil fraction in this region as well as other regions such as the Sahel and Saudi Arabia. This generates a large increase in the atmospheric dust loading, which affects the radiation balance in the region. Experiments where this radiative feedback is removed have shown that this contributes to an increased dry bias in the seasonal mean Indian rainfall, and that this dominates any other response to the vegetation distribution.

In the absence of radiative effects of changes in dust, a response to changes in the vegetation distribution over Eurasia can be discerned. In a similar manner to previous work, we find that changes in tree cover over northeast Eurasia are associated with changes in snow cover, which generate a dynamical response in the South Asian summer monsoon through their effects on the development of the meridional temperature gradient. Having demonstrated the sensitivity of the Asian summer monsoon to land cover changes in this model configuration in the present-day, we have subsequently shown that such changes also increase the climate change response of the monsoon, although we find that this is largely attributable to changes in the present-day simulation.

Our study suggests that, at least on the timescales examined here, the inclusion of interactive vegetation in this model plays a role both in the simulation of the present-day climatology of the Asian summer monsoon and in determining the projection of future monsoon rainfall. We would emphasise that many of our results may be specific to our model: it is possible that the signal over land may be different if there was not a general underestimation of rainfall over the Indian land in this model. However, the effect of this systematic bias on the monsoon rainfall through the large increase in atmospheric dust loading serves to illustrate how feedbacks between model biases can offset the benefits of including additional processes in a climate model. This is an important issue for model developers as climate models become increasingly complex. Thus, it is desirable that other modelling centres investigate these responses in other models where the biases may be different. This also highlights the importance of the development of robust metrics for evaluation of the additional processes represented in Earth System models.

In addition to the influence of additional processes such as interactive vegetation on the mean climatology of the Asian summer monsoon, perhaps an even more interesting aspect is the potential impact on monsoon variability and how this may change in future. Models struggle to reproduce 

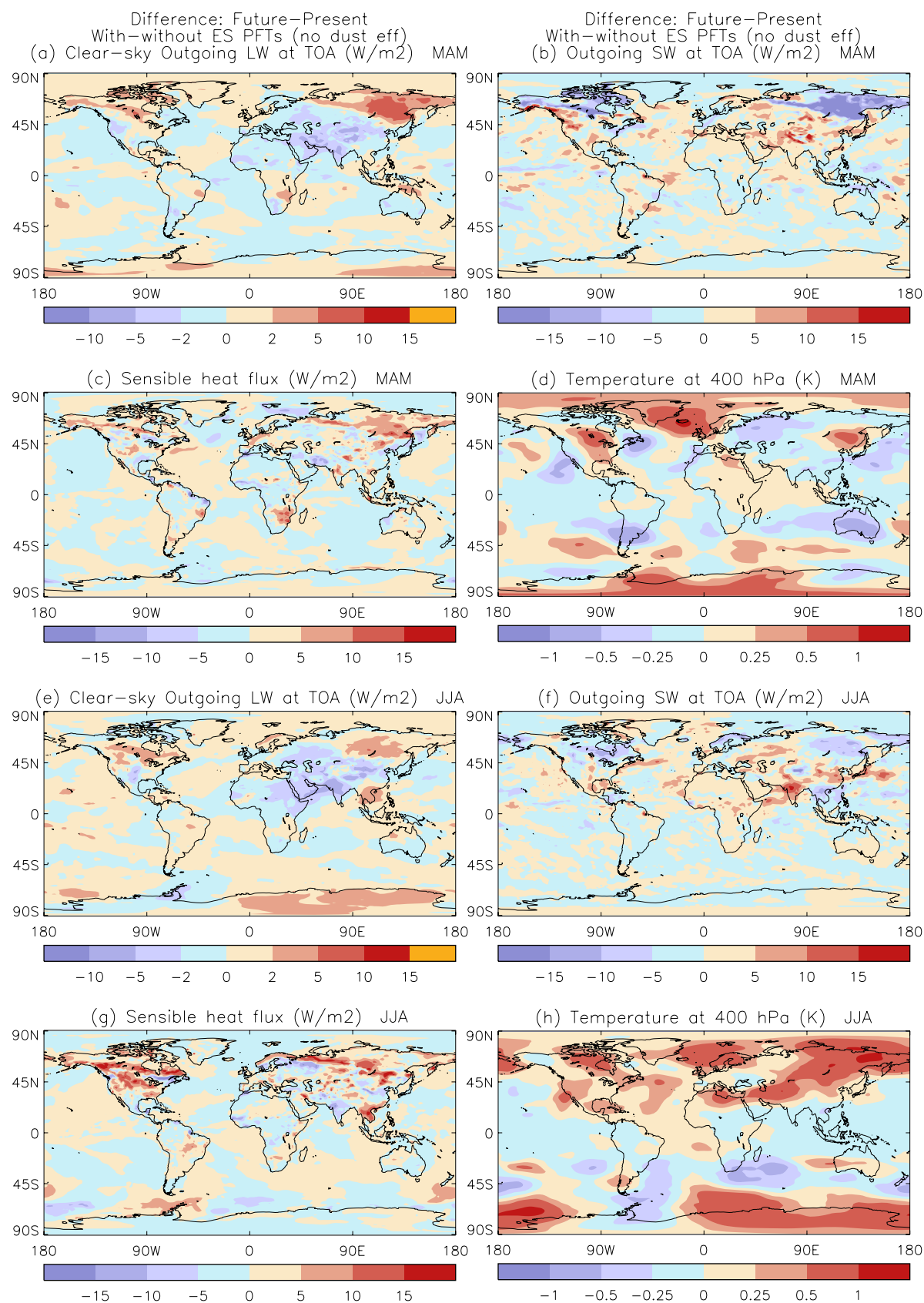

Fig. 18. As Fig. 16 but showing the impact of the ES land cover on the future-present differences (with no dust radiative effects).

present-day monsoon variability on a range of timescales from synoptic-scale to interannual, and there is considerable uncertainty in how this may change under global warming (Turner and Annamalai, 2012). The impact of dynamic vegetation in this model on the present-day simulation and future projections for Asian monsoon variability will be the subject of future work. In addition, the impacts (or lack thereof) of using dynamic vegetation in this model on other monsoon regions such as West Africa and East Asia will be examined.
Several previous studies have highlighted the influence of land cover (including both idealised changes and uncertainty in the present-day representation) on the tropical climate (e.g. Feddema et al., 2005; Swann et al., 2012; McCarthy et al., 2012) and its variability, including modes such as El Nino-Southern Oscillation (ENSO) which may affect the Asian monsoon indirectly (e.g. Hu et al., 2004). The role of other land surface processes and land usage such as irrigation in determining soil moisture, surface temperature and vegetation cover is also being investigated in observations and 
models (e.g. Douglas et al., 2008; Lee et al., 2009). A number of models within the CMIP5 ensemble include dynamic vegetation, in a similar manner to HadGEM2-ES. Our study suggests that the response of the dynamic vegetation to biases in regional climate, such as lack of rainfall over tropical dust-producing regions and changes in tree cover over northern Eurasia, can affect both the present-day simulation and the response to climate change forcing scenarios. Therefore, while the inclusion of dynamic vegetation that can respond to, and feed back on, changes in greenhouse gases may be important for constraining climate change projections, their inclusion further necessitates the reduction of basic model systematic biases in order to avoid feedbacks which may increase, rather than reduce, the uncertainty in tropical climate change.

Acknowledgements. The authors thank Hyo-Shin Lee and ChunHo Cho from the National Institute of Meteorological Research, Korea Meteorological Administration, for supplying data from their HadGEM2-AO CMIP5 historical simulation, and Charline Marzin from the Met Office for facilitating this. We acknowledge the World Climate Research Programme's Working Group on Coupled Modelling, which is responsible for CMIP. We also thank Susanna Stephenson for her preliminary work in analysing the impacts of $4 \mathrm{xCO}_{2}$ in HadGEM2-ES and -AO during her work experience at the Met Office, which provided the motivation for this study. This work was supported by the Joint DECC/Defra Met Office Hadley Centre Climate Programme (GA01101). This work is distributed under the Creative Commons Attribution 3.0 License together with an author copyright. This license does not conflict with the regulations of the Crown Copyright.

Edited by: N. Zeng

\section{References}

Baek, H.-J., Lee, J., Lee, H.-S., Cho, C. H., Kwon, W.-T., Marzin, C., Gan, S.-Y., Kim, M.-J., Hyun, Y.-K., Choi, D.-H., Lee, J., Lee, J., Boo, K.-O., Kang, H.-S., and Byun, Y.-H.: Climate change in the 21st century simulated by HadGEM2-AO under Representative Concentration Pathways, submitted to AsiaPacific J. Atmos. Sci., 2012.

Bonan, G. B., Pollard, D., and Thompson, S. L.: Effects of boreal forest vegetation on global climate, Nature, 359, 716-718, doi:10.1038/359716a0, 1992.

Booth, B. B., Jones, C. D., Collins, M., Totterdell, I. J., Cox, P. M., Sitch, S., Huntingford, C., Betts, R. A., Harris, G. R., and Lloyd, J.: High sensitivity of future global warming to land carbon cycle processes, Environ. Res. Lett., 7, 024002, doi:10.1088/17489326/7/2/024002, 2012.

Charlson, R. J., Lovelock, J. E., Andreae, M. O., and Warren, S. G.: Oceanic phytoplankton, atmospheric sulphur, cloud albedo and climate, Nature, 326, 655-661, doi:10.1038/326655a0, 1987.

Collins, W. J., Bellouin, N., Doutriaux-Boucher, M., Gedney, N., Halloran, P., Hinton, T., Hughes, J., Jones, C. D., Joshi, M., Liddicoat, S., Martin, G., O’Connor, F., Rae, J., Senior, C., Sitch, S., Totterdell, I., Wiltshire, A., and Woodward, S.: Development and evaluation of an Earth-System model - HadGEM2, Geosci. Model Dev., 4, 1051-1075, doi:10.5194/gmd-4-1051-2011, 2011.

Cox, P. M.: Description of the "TRIFFID" Dynamic Global Vegetation Model, Hadley Centre Technical Note No. 24, available from: http://www.metoffice.gov. uk/learning/library/publications/science/climate-science/

hadley-centre-technical-note, last access: 20 July 2012, Met Office Hadley Centre, Exeter, UK, 2001.

Cox, P. M., Betts, R. A., Jones, C. D., Spall, S. A., and Totterdell, I. J.: Acceleration of global warming due to carbon-cycle feedbacks in a coupled climate model, Nature, 408, 184-187, 2000.

Cubasch, U., Meehl, G. A., Boer, G. J., Stouffer, R. J., Dix, M., Noda, A., Senior, C. A., Raper, S., and Yap, K. S.: Projections of future climate change, in: Climate Change 2001: The Scientific Basis, edited by: Houghton, J. T., Ding, Y., Griggs, D. J., Noguer, M., van der Linden, P. J., Dai, X., Maskell, K., and Johnson, C. A., Cambridge University Press, 525-582, 2001.

Douglas, E. M., Beltrán-Przekurat, A., Niyogi, D., Pielke Sr., R. A., and Vörösmarty, C. J.: The impact of agricultural intensification and irrigation on land-atmosphere interactions and Indian monsoon precipitation - A mesoscale modeling perspective, Global Planet. Change, 67, 117-128, doi:10.1016/j.gloplacha.2008.12.007, 2008.

Douville, H. and Royer, J.: Sensitivity of the Asian summer monsoon to an anomalous Eurasian snow cover within the Météo-France GCM, Clim. Dynam., 12, 449-466, doi:10.1007/BF02346818, 1996.

Feddema, J., Oleson, K., Bonan, G., Mearns, L., Washington, W., Meehl, G., and Nychka, D.: A comparison of a GCM response to historical anthropogenic land cover change and model sensitivity to uncertainty in present-day land cover representations, Clim. Dynam., 25, 581-609, doi:10.1007/s00382-005-0038-z, 2005.

Friedlingstein, P., Cox, P., Betts, R., Bopp, L., von Bloh, W., Brovkin, V., Cadule, P., Doney, S., Eby, M., Fung, I., Bala, G., John, J., Jones, C., Joos, F., Kato, T., Kawamiya, M., Knorr, W., Lindsay, K., Matthews, H. D., Raddatz, T., Rayner, P., Reick, C., Roeckner, E., Schnitzler, K.-G., Schnur, R., Strassmann, K., Weaver, A. J., Yoshikawa, C., and Zeng, N.: Climate-carbon cycle feedback analysis, results from the C4MIP model intercomparison, J. Climate, 19, 3337-3353, doi:10.1175/JCLI3800.1, 2006.

Gordon, C., Cooper, C., Senior, C. A., Banks, H., Gregory, J. M., Johns, T. C., Mitchell, J. F. B., and Wood, R. A.: The simulation of SST, sea ice extents and ocean heat transports in a version of the Hadley Centre coupled model without flux adjustments, Clim. Dynam., 16, 147-168, doi:10.1007/s003820050010, 2000.

Hu, Z.-Z., Schneider, E. K., Bhatt, U. S., and Kirtman, B. P.: Potential mechanism for response of El Niño-Southern Oscillation variability to change in land surface energy budget, J. Geophys. Res., 109, D21113, doi:10.1029/2004JD004771, 2004.

Hurrell, J., Meehl, G. A., Bader, D., Delworth, T. L., Kirtman, B., and Wielicki, B.: A unified modeling approach to climate system prediction, B. Am. Meteorol. Soc., 90, 1819-1832, doi:10.1175/2009BAMS2752.1, 2009.

Hurtt, G. C., Chini, L. P., Frolking, S., Betts, R., Feddema, J., Fischer, G., Fisk, J. P., Hibbard, K., Houghton, R. A., Janetos, A., Jones, C., Kindermann, G., Kinoshita, T., Klein Goldewijk, K., Riahi, K., Shevliakova, E., Smith, S., Stehfest, E., Thomson, A., 
Thornton, P., van Vuuren, D. P., and Wang, Y.: Harmonization of Land-Use Scenarios for the Period 1500-2100: 600 Years of Global Gridded Annual Land-Use Transitions, Wood Harvest, and Resulting Secondary Lands, Climatic Change, 109, 117161, doi:10.1007/s10584-011-0153-2, 2011.

Jones, C. D., Cox, P. M., and Huntingford, C.: Impact of climate carbon cycle feedbacks on emission scenarios to achieve stabilization, in: Avoiding Dangerous Climate Change, edited by: Schellnhuber, H. J., Cramer, W., Nakicenovic, N., Wigley, T., and Yohe, G., Cambridge University Press, 322-332, 2006.

Jones, C. D., Hughes, J. K., Bellouin, N., Hardiman, S. C., Jones, G. S., Knight, J., Liddicoat, S., O’Connor, F. M., Andres, R. J., Bell, C., Boo, K.-O., Bozzo, A., Butchart, N., Cadule, P., Corbin, K. D., Doutriaux-Boucher, M., Friedlingstein, P., Gornall, J., Gray, L., Halloran, P. R., Hurtt, G., Ingram, W. J., Lamarque, J.-F., Law, R. M., Meinshausen, M., Osprey, S., Palin, E. J., Parsons Chini, L., Raddatz, T., Sanderson, M. G., Sellar, A. A., Schurer, A., Valdes, P., Wood, N., Woodward, S., Yoshioka, M., and Zerroukat, M.: The HadGEM2-ES implementation of CMIP5 centennial simulations, Geosci. Model Dev., 4, 543-570, doi:10.5194/gmd-4-543-2011, 2011.

Koster, R. D., Dirmeyer, P. A., Guo, Z., Bonan, G., Chan, E., Cox, P., Gordon, C. T., Kanae, S., Kowalczyk, E., Lawrence, D., Liu, P., Lu, C.-H., Malyshev, S., McAvaney, B., Mitchell, K., Mocko, D., Oki, T., Oleson, K., Pitman, A., Sud, Y. C., Taylor, C. M., Verseghy, D., Vasic, R., Xue, Y., and Yamada, T.: Regions of Strong Coupling Between Soil Moisture and Precipitation, Science, 305, 1138-1140, doi:10.1126/science.1100217, 2004.

Kuhlmann, J. and Quaas, J.: How can aerosols affect the Asian summer monsoon? Assessment during three consecutive premonsoon seasons from CALIPSO satellite data, Atmos. Chem. Phys., 10, 4673-4688, doi:10.5194/acp-10-4673-2010, 2010.

Lau, K. M. and Kim, K.-M.: Observational relationships between aerosol and Asian monsoon rainfall, and circulation, Geophys. Res. Lett., 33, L21810, doi:10.1029/2006GL027546, 2006.

Lee, E., Chase, T. N., Rajagopalan, B., Barry, R. G., Biggs, T. W., and Lawrence, P. J.: Effects of irrigation and vegetation activity on early Indian summer monsoon variability, Int. J. Climatol., 29, 573-581, doi:10.1002/joc.1721, 2009.

Levine, R. C. and Turner, A. G.: Dependence of Indian monsoon rainfall on moisture fluxes across the Arabian Sea and the impact of coupled model sea surface temperature biases, Clim. Dynam., 38, 2167-2190, doi:10.1007/s00382-011-1096-z, 2012.

Loveland, T. R., Reed, B. C., Brown, J. F., Ohlen, D. O., Zhu, Z., Yang, L., and Merchant, J. W.: Development of a global land cover characteristics database and IGBP DISCover from 1-km AVHRR data, Int. J. Remote Sens., 6, 1303-1330, doi:10.1080/014311600210191, 2000.

Martin, G. M., Milton, S. F., Senior, C. A., Brooks, M. E., Ineson, S., Reichler, T., and Kim, J.: Analysis and Reduction of Systematic Errors through a Seamless Approach to Modelling Weather and Climate, J. Climate, 23, 5933-5957, doi:10.1175/2010JCLI3541.1, 2010.

McCarthy, M. P., Sanjay, J., Booth, B. B. B., Krishna Kumar, K., and Betts, R. A.: The influence of vegetation on the ITCZ and South Asian monsoon in HadCM3, Earth Syst. Dynam., 3, 8796, doi:10.5194/esd-3-87-2012, 2012.
Meehl, G. A., Stocker, T. F., Collins, W. D., Friedlingstein, P., Gaye, A. T., Gregory, J. M., Kitoh, A., Knutti, R., Murphy, J. M., Noda, A., Raper, S. C. B., Watterson, I. G., Weaver, A. J., and Zhao, Z. C.: Global climate projections, in: Climate change 2007: the physical science basis, Contribution of working group I to the fourth assessment report of the intergovernmental panel on climate, edited by: Solomon, S., Qin, D., Manning, M., Chen, Z., Marquis, M., Averyt, K., Tignor, M. M. B., and Miller, H. L., Cambridge University Press, Cambridge, 2007.

Nigam, S. and Bollasina, M.: The "Elevated Heat Pump" Hypothesis for the Aerosol-Monsoon Hydroclimate Link: "Grounded" in Observations?, J. Geophys. Res., 115, D16201, doi:10.1029/2009JD013800, 2010.

Osborne, T. M., Lawrence, D. M., Slingo, J. M., Challinor, A. J., and Wheeler, T. R.: Influence of vegetation on the local climate and hydrology in the tropics: sensitivity to soil parameters, Clim. Dynam., 23, 45-61, doi:10.1007/s00382-004-0421-1, 2004.

Pope, V. D., Gallani, M. L., Rowntree, P. R., and Stratton, R. A.: The impact of new physical parametrizations in the Hadley Centre climate model: HadAM3, Clim. Dynam., 16, 123-146, doi:10.1007/s003820050009, 2000.

Ramanathan, V., Chung, C., Kim, D., Bettge, T., Buja, L., Kiehl, J. T., Washington, W. M., Fu, Q., Sikka, D. R., and Wild, M.: Atmospheric brown clouds: Impacts on South Asian climate and hydrological cycle, P. Natl. Acad. Sci., 102, 5326-5333, 2005.

Randall, D. A., Wood, R. A., Bony, S., Coleman, R., Fichefet, T., Fyfe, J., Kattsov, V., Pitman, A., Shukla, J., Srinivasan, J., Stouffer, R. J., Sumi, A., and Taylor, K. E.: Climate models and their evaluation, in: Climate Change 2007: The Physical Science Basis, edited by: Solomon, S., Qin, D., Manning, M., Chen, Z., Marquis, M., Averyt, K. B., Tignor, M., and Miller, H. L., Cambridge University Press, 589-662, 2007.

Ringer, M. A., Martin, G. M., Greeves, C. Z., Hinton, T. J., James, P. M., Pope, V. D., Scaife, A. A., Stratton, R. A., Inness, P. M., Slingo, J. M., and Yang, G.-Y.: The physical properties of the atmosphere in the new Hadley Centre Global Environmental Model (HadGEM1), Part II: Aspects of variability and regional climate, J. Climate, 19, 1302-1326, 2006.

Solomon, S., Qin, D., Manning, M., Chen, Z., Marquis, M., Averyt, K. B., Tignor, M., and Miller, H. L. (Eds.): Climate Change 2007: The Physical Science Basis, Cambridge University Press, 996 pp., 2007.

Swann, A. L. S., Fung, I. Y., and Chiang, J. C. H.: Mid-latitude afforestation shifts general circulation and tropical precipitation, $\mathrm{P}$. Natl. Acad. Sci., 109, 712-716, doi:10.1073/pnas.1116706108, 2012.

Taylor, K. E., Stouffer, R. J., and Meehl, G. A.: An Overview of CMIP5 and the experiment design, B. Am. Meteorol. Soc., 93, 485-498, doi:10.1175/BAMS-D-11-00094.1, 2012.

The HadGEM2 Development Team: Martin, G. M., Bellouin, N., Collins, W. J., Culverwell, I. D., Halloran, P. R., Hardiman, S. C., Hinton, T. J., Jones, C. D., McDonald, R. E., McLaren, A. J., O’Connor, F. M., Roberts, M. J., Rodriguez, J. M., Woodward, S., Best, M. J., Brooks, M. E., Brown, A. R., Butchart, N., Dearden, C., Derbyshire, S. H., Dharssi, I., Doutriaux-Boucher, M., Edwards, J. M., Falloon, P. D., Gedney, N., Gray, L. J., Hewitt, H. T., Hobson, M., Huddleston, M. R., Hughes, J., Ineson, S., Ingram, W. J., James, P. M., Johns, T. C., Johnson, C. E., Jones, A., Jones, C. P., Joshi, M. M., Keen, A. B., Liddicoat, S., Lock, A. P., 
Maidens, A. V., Manners, J. C., Milton, S. F., Rae, J. G. L., Ridley, J. K., Sellar, A., Senior, C. A., Totterdell, I. J., Verhoef, A., Vidale, P. L., and Wiltshire, A.: The HadGEM2 family of Met Office Unified Model climate configurations, Geosci. Model Dev., 4, 723-757, doi:10.5194/gmd-4-723-2011, 2011.

Turner, A. G. and Annamalai, H.: Climate change and the South Asian summer monsoon, Nat. Clim. Change, 2, 587-595, doi:10.1038/nclimate1495, 2012.

Turner, A. G. and Slingo, J. M.: Using idealized snow forcing to test teleconnections with the Indian summer monsoon in the Hadley Centre GCM, Clim. Dynam., 36, 1717-1735, doi:10.1007/s00382-010-0805-3, 2011.

Uppala, S. M., KÅllberg, P. W., Simmons, A. J., Andrae, U., Bechtold, V. D. C., Fiorino, M., Gibson, J. K., Haseler, J., Hernandez, A., Kelly, G. A., Li, X., Onogi, K., Saarinen, S., Sokka, N., Allan, R. P., Andersson, E., Arpe, K., Balmaseda, M. A., Beljaars, A. C.
M., Berg, L. V. D., Bidlot, J., Bormann, N., Caires, S., Chevallier, F., Dethof, A., Dragosavac, M., Fisher, M., Fuentes, M., Hagemann, S., Hólm, E., Hoskins, B. J., Isaksen, L., Janssen, P. A. E. M., Jenne, R., Mcnally, A. P., Mahfouf, J.-F., Morcrette, J.-J., Rayner, N. A., Saunders, R. W., Simon, P., Sterl, A., Trenberth, K. E., Untch, A., Vasiljevic, D., Viterbo, P., and Woollen, J.: The ERA-40 reanalysis, Q. J. Roy. Meteorol. Soc., 131, 2961-3012, 2005.

Xavier, P. K., Marzin, C., and Goswami, B. N.: An objective definition of the Indian summer monsoon season and a new perspective on the ENSO monsoon relationship, Q. J. Roy. Meteorol. Soc., 133, 749-764, doi:10.1002/qj.45, 2007.

Xie, P. and Arkin, P. A.: Global precipitation: A 17-year monthly analysis based on gauge observations, satellite estimates, and numerical model outputs, B. Am. Meteorol. Soc., 78, 2539-2558, 1997. 